\title{
MAKSUD-MAKSUD TUHAN DALAM MENETAPKAN SYARIAT DALAM PERSPEKTIF AL-SYATIBI
}

\author{
(مقاصد الشارع من وضع الشريعة عند الشاطبي) \\ Wahyuddin \\ Fakultas Syariah dan Ekonomi Islam IAIN Antasari Banjarmasin \\ E-Mail: wahyu_ulusalu@yahoo.com
}

\begin{abstract}
Maqashid al-Sharia is sharia purposes or secrets which are established by Allah. According to al-Syatib, there are four purposes of Allah to determine the shariah: (1). For the benefit of people in the world and the hereafter. (2). To be understood. (3). As a taklif law that must be implemented and to eliminate hardship. (4). To comply and freed from the influence of the passions mukallaf. The first mentioned purpose is the main aim, while other purposes only explains and details the first purpose. For the realization of such benefit, there are six essential components that must be maintained, namely: religion, life, intellect, lineage, wealth, and worshipers.
\end{abstract}

Abstrak: Maqashid al-syari'ah adalah tujuan-tujuan syariat atau rahasia-rahasia yang yang ditetapkan Allah swt. Menurut al-Syatibi tujuan Tuhan menetapkan syariat ada empat: (1). Untuk kemaslahatan manusia di dunia dan akhirat. (2). Untuk dipahami. (3). Sebagai suatu hukum taklif yang harus dilaksanakan dan menghilangkan kesukaran. (4). Untuk dipatuhi dan membebaskan mukallaf dari pengaruh hawa nafsu. Tujuan yang pertama disebutkan merupakan tujuan utama, adapun tujuantujuan yang lain hanya merupakan penjelasan dan perincian dari yang pertama. Untuk terwujudnya kemaslahatan tersebut, maka ada enam komponen penting yang harus dipelihara, yakni: agama, jiwa, akal, keturunan, harta, dan jamaah.

Kata Kunci: Maqashid al-syariah, kemaslahatan, bukum, syariat.

\section{Pendahuluan}

\section{Latar Belakang}

Syariat ${ }^{1}$ agama bersumber dari Allah swt. yang ditujukan kepada umat manusia, bertujuan untuk mengatur sikap dan perilaku manusia, dalam merealisasikan pernyataan penghambaannya kepada Allah swt., agar memperoleh kemaslahatan hidup, baik di dunia maupun kelak di akhirat.

Tuntunan terhadap sikap dan perilaku tersebut bercabang dua, yakni yang berorientasi kepada Allah swt., yang dalam "bahasa agama" disebut hablun min Allah dan yang berorientasi kepada sesama manusia yang disebut bablun min annas. Dalam Alquran, Allah swt. memberikan jaminan bahwa apabila kedua hal tersebut dapat diwujudkan oleh manusia secara serasi dan

\footnotetext{
Syariat atau sariat, keduanya telah baku dalam bahasa Indonesia. Syariat secara leksikal, berasal dari lafal verba Arab: - شرع - يشرع - شرعا - شارع - مشروع syari'atan adalah sigat mubalagah dari lafal masyra'an yang berarti "al-tariqah al-mustaqimab", atau "maurid al-mai li al-syarib" (jalan yang lurus atau sumber mata air bagi yang minum). Lihat catatan kaki Minhajuddin, Ikbtilaf Ulama Sunni dan Pengarubnya terhadap Perkembangan Fikih Islam dalam Zaitun, Volume I Nomor II Maret Tahun 2003, h. 15.
}

terpadu, manusia akan mendapatkan kebahagian yang paripurna lagi abadi. Sebaliknya, jika diabaikan, manusia akan memperoleh kehinaan (Q.S. 'Ali Imran [3]: 112).

Berdasarkan informasi Alquran tersebut, menjadi jelaslah bahwa semua syariat agama bertujuan untuk kemaslahatan manusia. Ini berarti hukum-hukum taklifi yang wajib dilaksanakan oleh manusia, orientasinya kepada manusia; bukan untuk Allah swt., untuk para rasul, dan untuk para malaikat.

Bertolak dari alur pikir yang di kedepankan diatas, dapat dipahami bahwa secara khusus semua perintah dan larangan yang terdapat dalam hukum-hukum syari'ah, memiliki alasan logis yang rasional, yang kesemuanya tidak ada sama sekali bertentangan dengan nilai-nilai fitrah insaniah. Ini mengandung arti bahwa subtansi dari ketentuan-ketentuan hukum syariah sangat relevan dengan nilai-nilai kemanusiaan.

Konsep maslahat seperti yang digambarkan di atas, dieksplorasi oleh Imam al-Syatibi. Dalam menjelaskan konsep ini, al-Syatibi antara lain mengatakan: 
و المعتمد إنما هو أنا استقرينا من الشريعة أها وضعت لمصالح العباد

استقراء

"Yang mu'tamad bila kita betul-betul mencermati tujuan ditetapkannya syari'ah adalah kemaslahatan manusia".

Dari ungkapan al-Syatibi di atas, dapat dipahami bahwa kandungan maqashid syariah adalah kemaslahatan umat manusia itu sendiri. Dalam bagian terbesar dari karya monumentalnya, al-Muwafaqat, al-Syatibi lebih jauh menjelaskan bahwa tujuan akhir ditetapkannya hukum adalah satu, yaitu kemaslahatan bagi manusia baik di dunia maupun di akhirat.

Pengetahuan terhadap maqashid syariah dipandang penting karena ia merupakan landasan bagi seorang mujtahid, baik dalam usaha mengembangkannya untuk menjawab persoalanpersoalan baru yang tidak didapati hukumnya secara harfiah dalam wahyu, maupun dalam kepentingan untuk mengetahui, apakah terhadap satu kasus masih dapat diterapkan karena pergeseran nilai disebabkan perubahan stuktur sosial dan sebagainya.

\section{Rumusan Masalah}

Berangkat dari latar belakang tersebut diatas, maka artikel ini dimaksudkan untuk mencoba menguraikan konsep maqashid syariah. Untuk terpokusnya pembahasan ini, maka penulis merumuskan masalah sebagai berikut:

1. Apa yang dimaksud dengan maqashid syariah?

2. Apa tujuan konsep maqashid syariah itu?

\section{Sekilas tentang Makna Maqashid Syari'ah}

Sebelum melanjutkan tulisan ini dipandang perlu mengemukakan makna maqashid syari'ah, maqashid syariah adalah makna-makna dan tujuan-tujuan yang ditetapkan bagi syariat dalam seluruh hukum-hukumnya atau pada umumnya, atau tujuan dari syariat, atau rahasia-rahasia yang ditetapkan Allah swt. (al-Syari) bagi setiap hukum dari hukum-hukumnya. ${ }^{3}$ Mengetahui maqashid syariah adalah sesuatu yang cukup signifikan bagi manusia, seorang mujtahid dituntut untuk memperhatikannya ketika ia hendak mengistimbatkan hukum-hukum dan

2 Al-Syatibiy, al-Muwafaqat fi Ushul al-Syari'ah, Juz II (Beyrut: Dar al-Kutb al-'Ilmiayah, t. th. ), h. 4.

3 Wahbat al-Zuhailiy, Ushul al-Figh al-Islamiy, Juz II (Cet. II; Bayrut: Dar al-Fikr, 1998), h. 145. memahami nash-nash, bagi selain mujtahid tujuannya untuk mengetahui rahasia-rahasia tasyri ${ }^{4}$

Perbincangan mengenai masalah apakah Tuhan mempunyai tujuan dalam membuat atau menetapkan suatu hukum cukup menarik perhatian para pakar. Perbincangan tersebut bukan hanya terjadi di kalangan para filosof saja melainkan juga terjadi di kalangan para teolog dan ahli ushul. Dalam filsafat agama, terdapat satu golongan yang berpendapat bahwa segala kejadian di alam ini terjadi secara seketika tanpa dirancang sebelumnya. Faham ini disebut occasionalism. Menurut paham ini, jika ada dua peristiwa yang kelihatannya serasi dan sejalan, sebenarnya itu hanya terjadi secara seketika, karena hal itu dibuat dalam keadaan demikian oleh Tuhan; seperti halnya dua jam dapat menunjukkan waktu yang sama karena diciptakan demikian oleh pembuatnya. ${ }^{5}$ Faham inilah yang kemudian dikembangkan oleh aliran teologi Asyari'ah yang dasar pemikirannya memandang Tuhan sebagai Penguasa langit dan bumi yang segala kemauan-Nya tak dapat ditolak dan tak dapat dimengerti ia dapat berbuat tanpa tujuan. Pokoknya menurut mereka segala kejadian dalam alam tergantung sepenuhnya pada kehendak mutlak Tuhan. ${ }^{6}$

Berbeda dengan pandangan tersebut di atas, Muhammad Abduh dan Fazlur Rahman serta dua aliran teologi, Mu'tazilah dan Maturidiyah serta al-Syatibiy, semua sependapat bahwa Tuhan mempunyai tujuan tertentu dalam perbuatanNya. Dalam mengadakan syariat, tujuan Tuhan adalah terwujudnya kemaslahatan manusia di dunia dan akhirat (mashalih al-ibad fi ad-darain). ${ }^{7}$ Pandangan al-syatibi tersebut dipahami antara lain dari pernyataanya sebagai berikut:

و المعتمد إنما هو أنا استقرينا من الشريعة أنما وضعت لمصالح العباد استقراء

$$
\text { لا ينازع فيه الرازي, و لا غيره. }
$$

Untuk mendukung pernyataan tersebut ia mengutip beberapa ayat Alquran antara lain Q.S. al-Nisa [4]: 165.

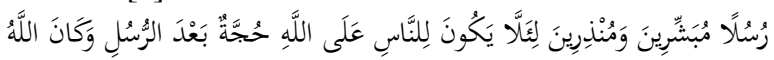

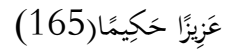

Terjemahnya:

4 Ibid., h. 145

5 Hamka Haq, Falsafat Ushul Fiqhi (Makassar: Yayasan Al-Ahkam, t. th.), h. 45-46.

6 Ibid., h. 46.

Ibid., h. 56.

8 Al-Syatibi, loc. cit. 
(Mereka kami utus) selaku rasul-rasul pembawa berita gembira dan pemberi peringatan agar supaya tidak ada alasan bagi manusia membantah Allah sesudah diutusnya rasul-rasul itu. Dan adalah Allah Maha Perkasa lagi Maha Bijaksana. ${ }^{9}$

\section{Tujuan Syariat Untuk Kemaslahatan Manusia di Dunia dan Akhirat}

Al-Syatibi yang dikenal sebagai penggagas maqashid syariah membagi maqashid dalam dua bentuk, pertama maqashid syari'ah, kedua maqashid al-mukallaf. maqashid yang pertama disebutkan dibagi lagi menjadi empat macam. (1). Maksud Tuhan menetapkan syariat untuk kemaslahatan dunia dan akhirat. (2). Maksud Tuhan menetapkan syariat untuk dipahami. (3). Maksud Tuhan menetapakan syariat untuk dibebankan. (4). Maksud Tuhan dalam memasukkan mukallaf di bawah hukum-hukum syariat. Adapun maqashid al-mukallaf ia hanya menguraikan dalam beberapa permasalahan atau dengan kata lain ia tidak membaginya dalam beberapa macam. ${ }^{10}$

قصد الشارع ف Dalam komentarnya ia mengatakan ب. Abdullah Darraz (pentahqiq kitab al-Muwafaqat) menjelaskan makna ابتداء dengan mengatakan maksud pertama yaitu kemaslahatan manusia di dunia dan akhirat dan inilah yang merupakan peringkat pertama, adapun maksudmaksud yang lain seperti untuk dipahami, untuk dibebankan dan sebagainya hanyalah merupakan penjelasan dan perincian dari yang pertama. ${ }^{11}$

Seperti yang telah disinggung di atas, bahwa tujuan Allah swt. mensyariatkan hukumnya adalah untuk memelihara kemaslahatan manusia, sekaligus menghindari mafsadat, baik di dunia maupun di akhirat. Tujuan tersebut hendaknya dicapai melalui taklif, yang pelaksanaanya tergantung pada pemahaman akan sumber hukum yang utama, Alquran dan Hadis. Dalam rangka mewujudkan kemaslahatan di dunia dan di akhirat, berdasarkan penelitian para pakar ushul fiqih, ada lima unsur pokok yang harus dipelihara dan diwujudkan, kelima pokok tersebut adalah agama, jiwa, akal, keturunan dan harta, ${ }^{12}$ urutan inilah yang paling kuat. Kelima

Dikutip dari CD Alquran (Govathu Collction).

10 Ahmad, Nazariah al-Maqashid inda al-Imam al-Syatibiy (Cet. I; t. t: al-Muassasah al-Jāmi'iyah li al-Dirāsāt wa al-Nusyu wa al-Tauzi', 1992), h. 116.

11 Lihat catatan kaki al-Syatibiy, loc. cit.

12 Lihat Muhammad Abu Zahrah, Tarikh al-Marabib alIslamiyah fi al-Siyasah wa al-'Aqaid wa Tärikh alMazabib al-Fiqbiyah (Mesir: Dar al-Fikr al-'Arabiy, t. aspek tersebut telah disepakati bukan saja oleh ulama Islam melainkan juga oleh keseluruhan agamawan. ${ }^{13}$ Perlu dikemukakan disini bahwa masih ada satu hal lagi yang oleh oleh Hamka Haq dimasukkan sebagai salah satu bagian yang sangat urgen untuk dipelihara, bahkan ia menempatkannya pada urutan kedua setelah agama, yakni memelihara jamaah. ${ }^{14}$ Seorang mukallaf akan memperoleh kemaslahatan, bila ia memelihara kelima atau keenam unsur pokok tersebut, sebaliknya ia akan merasakan mafsadat, manakala ia tidak dapat memelihara kelima atau keenam unsur itu dengan baik.

Tujuan pokok syariat yang disebutkan diatas, yang jumlahnya lima atau enam aspek, masingmasing memiliki urgensi yang bervariasi. Setiap aspek tersebut urgensinya dapat dibedakan dalam tiga tingkatan, yakni (1). Primer (dharuriyah). (2). Sekunder (Hajiyah). (3). Tertier (tabsiniyah). Untuk sistematisnya uraian ini maka penulis akan menguraikan satu persatu.

1. Primer (dharuriyah) ialah segala hal yang bersifat esensial bagi kehidupan manusia dan karena itu wajib ada sebagai syarat mutlak terwujudnya kehidupan dan kemaslahatan manusia, baik ukhrawi maupun duniawi. Dengan kata lain andaikata dharuriyah ini tidak terwujud, niscaya kehidupan manusia akan punah sama sekali.

2. Sekunder (bajiyah) adalah segala yang menjadi kebutuhan primer manusia dalam hidupnya agar hidupnya menjadi bahagia dan sejahtera dunia akhirat serta terhindar dari berbagai kemelaratan. Jika kebutuhan ini tidak diperoleh maka kehidupan manusia akan pasti mengalami kesulitan (masyaqqah) meskipun kehidupan mereka tidak sampai punah.

3. Tertier (tabsiniyah), yakni suatu kebutuhan hidup yang sifatnya komplomenter dan lebih menyempurnakan kesejahteraan hidup manusia. Jika kemaslahatan yang terakhir ini tidak terpenuhi, maka kemaslahatan hidup manusia kurang indah dan kurang nikmat,

th. ), h. 294. Muhammad Abu Zahrah, Ushul al-Fiqh (t. d), h. 367.

13 Lihat Juhaya S. Praja, Filsafat Hukum Islam (Cet. I; Bandung: Yayasan Piara Bandung, 1993), h. 152.

14 Lihat Hamka Haq, op. cit., h. 79. 
kendatipun tidak sampai menimbulkan kemeralatan dan kebinasaan hidup..$^{15}$

Seperti telah dikemukakan, masing-masing dari lima perkara yang telah disebutkan sebagai tujuan pokok syariat pada dasarnya dapat dilihat dari tiga sisi tersebut. ${ }^{16}$

1. Memelihara agama dalam peringkat dharuriyah, yakni memelihara dan melaksanakan kewajiban keagamaan yang masuk peringkat primer, seperti melaksanakan shalat lima waktu. Kalau shalat itu diabaikan, maka terancamlah eksistensi agama. Memelihara agama dalam peringkat hajiyah, yaitu melaksanakan ketentuan agama, dengan maksud menghindari kesulitan, seperti shalat jamak dan shalat qashar bagi seseorang yang sedang bepergian. Kalau ketentuan ini tidak dilakukan, maka tidak akan mengancam eksistensi agama, melainkan hanya mempersulit orang yang melakukannya. Memelihara agama dalam peringkat tabsiniyah, seperti menutup aurat, baik di dalam shalat maupun di luar shalat, membersihkan pakaian dan tempat. Kegiatan ini erat kaitannya dengan ahlaq yang terpuji. Kalau hal ini tidak mungkin untuk dilakukan, maka hal ini tidak mengancam eksistensi agama dan tidak pula mempersulit orang yang melakukannya. Artinya bila tidak ada penutup aurat, seseorang boleh shalat, jangan sampai meninggalkan shalat yang termasuk kelompok dharuriyah. Kelihatannya menutup aurat tidak dapat dikategorikan sebagai pelengkap (tabsiniyab), karena keberadaannya sangat diperlukan bagi kepentingan manusia. Setidaknya kepentingan ini dimasukkan dalam kategori hajizah dan dharuriyah. Namun kalau mengikuti pengelompokan di atas, tidak berarti sesuatu yang termasuk tabsiniyah itu di anggap tidak penting, karena kelompok ini akan menguatkan kelompok hajiyah dan dharuriyab. ${ }^{17}$

2. memelihara jiwa (bifz al-nafs), dalam peringkat dharuriyah, seperti memenuhi kebutuhan

15 Hamka Haq, op. cit., h. 76. lihat pula Amir Syaripuddin, Uiul Fiqh, Jilid II (Cet. II; Jakarta: PT Logos Wacana Ilmu, 2001), h. 209-214.

17 Fathurrahman Djamil, Filsafat Hukum Islam, Bagian Pertama (Cet. I; Jakarta: Logos Wacana Ilmu, 1997), h. 128-129. Bandingkan dengan Hamka Haq, op. cit., h.77. lihat juga Muhammad Syah, dkk, Filsafat Hukum Islam (Cet. II; Jakarta: Bumi Aksara, 1992), h. 67-101. pokok berupa makanan untuk mempertahankan hidup. Kalau kebutuhan pokok ini diabaikan, maka akan berakibat terancamnya jiwa. Memelihara jiwa (bifz alnafs), dalam peringkat bajiyah, seperti diperbolehkannya berburu binatang untuk menikmati makanan yang lezat dan halal. Kalau kegiatan ini diabaikan, maka tidak akan mengancam eksistensi manusia, melainkan hanya mempersulit hidupnya. Memelihara jiwa (bifz al-nafs), dalam peringkat tabsiniyah seperti ditetapkannya tata cara makan dan minum. Kegiatan ini hanya berhubungan dengan kesopanan dan etika, sama sekali tidak akan mengancam eksistensi jiwa manusia, ataupun mempersulit kehidupan seseorang. ${ }^{18}$

3. Memelihara akal (bifz al-'aq), memelihara akal dalam peringkat dharuriyah, seperti diharamkam meminum minuman keras. Jika ketentuan ini tidak diindahkan, maka akan berakibat terancamnya eksistensi akal. Memelihara akal dalam peringkat hajiyah, seperti dianjurkannya menuntut ilmu pengetahuan. Sekiranya hal ini dilakukan, maka tidak akan merusak akal, tetapi akan mempersulit diri seseorang, dalam kaitannya dengan pengembangan ilmu penegetahuan. Memelihara akal dalam tingkat tabsiniyah, seperti menghindarkan diri dari menghayal atau mendengarkan sesuatu yang tidak berguna. Hal ini tidak mengancam eksistensi akal secara langsung. ${ }^{19}$

4. Memelihara keturunan (bifz al-nas), dalam peringkat dharuriyah, seperti disyariatkannya nikah dan dilarangnya berzina. Kalau kegiatan ini diabaikan, maka eksistensi keturunan akan terancam. Memelihara keturunan dalam peringkat hajizah, misalnya ditetapkannya ketentuan menyebutkan mahar bagi suami pada waktu akad nikah dan diberikan hak talaq padanya. Jika mahar itu tidak disebutkan pada waktu aqad, maka suami akan mengalami kesulitan, karena ia harus membayar mahar misthl. Sementara dalam kasus talak, suami akan mengalami kesulitan, jika tidak menggunakan hak talaknya, padahal situasi di rumah tanggahnya tidak harmonis lagi. Memelihara keturunan dalam peringkat tabsiniyah, seperti disyariatkannya kbitbah atau walimah dalam

18 Fathurrahman Djamil, op. cit. , h. 129.

19 Fathurrahman Djamil, op. cit. , h. 129-130. 
perkawinan. Hal ini dilakukan dalam rangka melengkapi kegiatan perkawinan. Jika hal ini diabaikan, maka tidak akan mengancam eksistensi keturunan, dan tidak pula mempersulit orang yang melakukan perkawinan. ${ }^{20}$

5. Memelihara harta (bifz al-mal), dalam peringkat dharuriyah, seperti syaraiat tentang tata cara pemilikan harta dan larangan mengambil harta orang lain dengan cara yang tidak sah. Apabila ketentuan ini diabaikan, maka berakibat terancamnya eksistensi harta. Memelihara harta pada tataran hajizah, misalnya syariat tentang jual beli dengan cara salam, apabila cara ini tidak dipakai, maka tidak mengancam eksistensi harta, melainkan akan mempersulit orang yang memerlukan modal. Memelihara harta dalam peringkat tabsiniyah, seperti ketentuan tentang menghindarkan diri dari pengecohan atau penipuan. Hal ini erat kaitannya dengan persoalan bisnis. Hal ini juga akan berpengaruh kepada sah tidaknya jual beli itu, sebab peringkat yang ketiga ini juga merupakan syarat adanya peringakat kedua dan pertama. ${ }^{21}$

6. Memelihara jamaah dalam artian stabilitas sosial. Jika beribadah kepada Tuhan dipandang paling utama dan penting karena merupakan landasan segenap aspek kehidupan manusia, maka hubungan dengan sesama manusia dalam suatu tatanan sosial berupa negara (jamaah) adalah penting karena segenap aspek kehidupan duniawi dan agama hanya dapat terlaksana jika manusia dapat membangun kehidupan masyarakat. Itulah sebabnya dalam QS Âl Imran [3]: 112, ditegaskan bahwa manusia akan dilanda kehinaan kecuali jika menjaga hubungannya dengan Tuhan dan hubungannya dengan

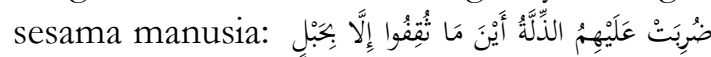
Puncak hubungan antar sesama manusia ialah terbentuknya suatu kehidupan masyarakat dan negara yang stabil. Bahkan dalam salah satu riwayat disebutkan bahwa mereka yang sengaja memisahkan diri dari jamaah, dalam artian melakukan tindakan subversif, diancam hukuman mati

Fathurrahman Djamil, op. cit. , h. 130.

21 Fathurrahman Djamil, op. cit. , h. 131. Lihat juga Minhajuddin, Sistimatika Filsafat Hukum Islam Ibadah Mia'amalah Perkawinan Jinayat Peradilan Keadilan (Ujungpandang: Yayasan Ahkam, 1996), h. 39. (halal darahnya), sama hukumnya dengan mereka yang berzina dan murtad. Hal ini menunjukkan bahwa kepentingan jamaah jauh lebih penting daripada jiwa seseorang yang melakukan tindak subversif itu. ${ }^{22}$

\section{Tujuan Syariat untuk Dipahami}

Alquran adalah kalam Allah swt. yang diturunkan kepada nabi Muhammad saw. dengan lafal-lafal bahasa Arab, agar menjadi hujjah Rasululah saw. dalam pengakuannya sebagai Rasulullah, juga sebagai undang-undang yang menjadi pedoman umat manusia dan sebagai amal yang bernilai ibadah bagi yang membacanya. ${ }^{23}$ Salah satu tujuan syariat adalah untuk dipahami. Pada dasarnya kajian ini meliputi dua aspek, pertama syariat ini adalah bahasa Arab kedua syariat ini adalah ummi. ${ }^{24}$ Kedua aspek tersebut memiliki hubungan yang sangat erat dengan kajian tujuan syariat, yakni pemahaman yang benar akan syariat serta tujuantujuannya tidak mungkin dapat terwujud kecuali melalui dua aspek tersebut.

Aspek pertama, yakni syariat itu adalah bahasa Arab, dengan demikian tidak ada bahasa lain untuk yang dapat mengantar kita memahaminya dengan benar, kecuali dengan memahami bahasa Arab dari berbagai aspeknya. Aspek kedua, yakni syariat itu adalah ummi maksudnya syariat itu tidak membutuhkan ilmu-ilmu alam, riya a untuk memahaminya. 25 Karena syariat itu diturunkan kepada Rasullah yang ummi. Kata ummi di sini memiliki dua pengertian, pertama Rasulullah saw. tidak memiliki ilmu orang-orang terdahulu (ahli Kitab), yang kedua Rasulullah tidak tidak memiliki kemamampuan membaca dan menulis. ${ }^{26}$

Bila ditelusuri lebih jauh, maka ditemukan bahwa aspek yang pertama disebutkan di ataslah yang membawa kepada persoalan apakah terjemahan-terjemahan Alquran dapat mengantar seseorang untuk memahami Alquran ?. untuk menjawab persoalan ini ada baiknya dikemukakan pandangan al-Syatibi dalam kaitannya dengan dalalah (petunjuk), suatu lafal, dalam hal ini ia membagi dalālab (petunjuk), suatu lafal dalam dua segi:

22 Hamka Haq, op. cit. , h. 73-74.

23 Lihat Abd Wahhāb Khallāf, $\operatorname{Im} U_{i j} \bar{l}$ alp-Figh (t. d), h. 23.

24 Ahmad, op. cit., h. 120.

25 Lihat catatan kaki al-Syatibiy, op. cit., h. 53.

26 Ibid. , h. 53. 
1. Lafal dan ibarat yang mutlaq menunjukkan makna yang mutlaq, itulah yang dikatakan dalalah aqliyyah.

2. Lafal dan ibarat yang muqayyad, menunjukkan kepada makna tambahan. Itulah yang disebut dalalah tabi'ab27.

Menurut al-Syatibi, segi yang pertama (dalalah aqliyyah) terdapat dalam semua bahasa, atau dengan kata lain tidak ada perbedaan antara satu bahasa dengan bahasa lainnya. Misalnya dalam memeberitakan orang berdiri. Hal ini dapat dituturkan atau diungkapkan dalam semua bahasa. Akan tetapi bila ungkapan itu dimaksudkan untuk penekanan kepada seseorang, menurut al-Syatibi masuk ke dalam segi kedua (dalalah tabi'ah) dan hal ini khusus bagi bahasa Arab, karena lisan Arab senantiasa memperhatikan keadaan mukhbir (pemberi berita), mukhbar anh (orang yang diberitakan), nafs al-ikhbar (berita yang sama), nau' al-uslub (ragam gaya bahasa), al-idah (jelas), ikhfa (samar), I'jaz. (ringkasan), dan sebagainya. ${ }^{28}$

Berangkat dari spesifikasi bahasa Arab seperti yang telah digambarkan pada segi yang kedua di atas. sehingga al-syatibi memandang tidak mungkin menerjemakan bahasa Arab ke dalam bahasa lain. Demikian juga halnya dengan penerjemahan Alquran kedalam bahasa lain. Namun apabila penerjemahan itu dimaksudkan pada segi yang pertama disebutkan, yakni dalalah aqliyyah, maka itu boleh saja bahkan sudah menjadi kesepakatan di kalangan umat Islam. Dari sini dapat disimpulkan bahwa memahami Alquran melalui terjemahannya adalah tidak cukup untuk tidak mengatakan mustahil.

Berdasarkan uraian di atas, maka dapatlah dipahami bahwa untuk menggali makna-makna yang dikandung oleh Alquran haruslah memahami dengan baik lafal-lafal yang ma'bud (terkenal) di kalangan bangsa Arab dikala Alquran diturunkan. Begitu urgennya bahasa Arab dalam pengkajian tafsir, sehingga tidak jarang ditemukan mufassir menggunakan syairsyair jahiliyah sebagai salah satu pisau analis dalam menginterpretasi ayat-ayat Alquran.

Tujuan Syariat sebagai Hukum Taklif yang Harus Dilaksanakan dan Menghilangkan Kesukaran

Tabiat manusia tidak menyukai beban yang membatasi kemerdekaannya dan manusia

Ibid., h. 51.

28 Ibid., h. 51. senantiasa memperhatikan beban hukum dengan sangat teliti dan hati-hati. Manusia tidak bergerak mengikuti perintah kecuali kalau perintahperintah itu dapat menarik hatinya, mempunyai daya dinamika, kecuali perintah yang dikerjakan dengan keterpaksaan. Syariat Islam dapat menarik manusia dengan amat cepat dan mereka dengan mudah menerimanya dengan ketetapan hati. Hal ini adalah karena Islam menjunjung tinggi sikap rasionalitas.

Syariat Islam senantiasa memberikan kemudahan dan menjauhi kesulitan, semua hukumnya dapat dilaksanakan oleh umat manusia. Karena itu dalam hukum Islam dikenal istilah rukhsah (peringanan hukum). Contoh dari rukshah yang dapat disebutkan disini adalah kebolehan berbuka bagi musafir yang merasa tidak kuat berpuasa. Di samping itu, dalam Islam juga dikenal istilah dharurah (hukum yang berlaku pada saat keterpaksaan). Contoh dharurah adalah kebolehan memakan makanan yang diharamkan apabila terpaksa. Penetapan ini didasarkan pada kaidah fiqh:29

$$
\text { الضرورات تبيح المخظورات }
$$

"Keadaan terpaksa menjadikan apa yang semula terlarang, dibolehkan"

Ayat-ayat Alquran yang menunjukkan bahwa beban kewajiban bagi manusia tidak pernah memberatkan adalah sebagai berikut:

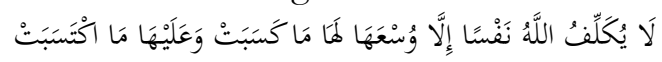

"Allab tidak membebani seseorang melainkan sesuai dengan kesanggupannya".30 (Q.S. al-Baqarah [2]: 286).

$$
\text { يُرِيدُ اللَّهُ بِكُمُ الْْيُسْرَ وَلَا يُرِيدُ بِكُمُ الْعُسْرَ }
$$

"Allah menghendaki kemudahan bagimu, dan tidak menghendaki kesukaran bagimu”. ${ }^{31}$ (Q.S. al-Baqarah [2]: 185).

$$
\text { مَا يُرِيدُ اللَّهُ لِيْجْعَل عَلَيْكُمْ مِنْ حَرِجِ }
$$

"Allah tidak bendak menyulitkan kamu".32 (Q.S. alMaidah [5]: 6).

Perbuatan manusia, dapat dipandang dari dua aspek, yakni aspek terwujudnya kemaslahatan itu dan aspek tuntunan syariat. Dari dua aspek ini dapat dilihat bagaimana tanggung jawab manusia sebagai mukallaf. Pada aspek terwujudnya kemaslahatan, daya manusia menjadi syarat utama berlakunya taklif, dan mustahil ada tuntutan di luar daya manusia (talif ma la yutaq).

29 Fathurrahman Djamil, op. cit., h. 66-67.

30 Dikutip dari $C D$ Alquran (Govathu Collction).

31 Dikutip dari $C D$ Alquran (Govathu Collction).

32 Dikutip dari CD Alquran (Govathu Collction). 
Sedangkan pada aspek tuntutan syariat, pembicaraan berkaitan dengan iradah (kehendak) dan amr (perintah) Tuhan kepada hamba-Nya. Masalah ini berkaitan pula dengan konsekuensi perbuatan manusia dan siksaan di akhirat. ${ }^{33}$

Sebagai disebutkan di atas, daya atau kemampuan yang dimiliki manusia merupakan syarat utama bagi berlakunya hukum taklif. Dari segi ini, perbuatan atau keadaan pada diri manusia dapat dibedakan dalam dua bentuk, yakni: pertama, perbuatan atau keadaan di luar daya manusia, kedua, perbuatan atau keadaan dalam batas daya manusia. Contoh perbuatan yang disebutkan pertama menurut al-syatibi, haid menjadi halangan bagi shalat, puasa dan tawaf dan lain sebagainya. Sedang bentuk kedua, adalah segenap perbuatan sadar yang menjadi objek taklif, baik yang diperintahkan maupun yang dilarang serta yang diizinkan demi terwujudnya kemaslahatan. Demikian pula semua perbuatan yang masuk dalam kategori wad'iy yang wujudnya tergantung pada pada usaha manusia sendiri, contoh konkret menurut al-Syatibiy, adalah jual beli, nikah, kepatuhan, menyembeli hewan, minum khamar, berzina, mencuri dan sebagainya. ${ }^{34}$

Dari dua macam perbuatan manusia yang disebutkan di atas, bentuk yang dapat dinilai secara syariat dan dikenakan hukum taklif hanyalah perbuatan berdasarkan daya (qudrab) manusia sendiri. Tampak jelas bahwa baik dari segi terwujudnya kemaslahatan maupun dari segi tuntutan syariat, al-Syatibi menekankan daya (qudrab) manusia sendiri sebagai faktor dan syarat utama. ${ }^{35}$

Sehubungan dengan itu, perbuatan manusia dapat dibagi ke dalam dua jenis, yakni perbuatan lahir dan perbuatan batin. Dalam kaitannya dengan daya manusia, dua jenis perbuatan tersebut terjadi dalam tiga keadaan: ${ }^{36}$

1. Perbuatan atau keadaan yang pasti berada di luar daya manusia, misalnya kematian. Keadaan semacam ini tidak menjadi tuntutan syariat, karena itu ayat yang berbunyai bukanlah menyangkut kematian itu sendiri, melainkan perbuatan sebelum kematian, yakni keislaman.

2. Perbuatan yang wujudnya diusahakan secara pasti oleh manusia, dan menjadi tuntutan

33 Hamka Haq, op. cit., h. 151.

34 Ibid., h. 152.

35 Ibid., h. 152.

36 Ibid., h. 153. atas manusia, baik menyangkut perbuatan itu sendiri, maupun perbuatan lain yang berkaitan dengannya.

3. Perbuatan yang samar-samar berada di antara dua keadaan di atas, misalnya rasa cinta, benci dan semacamnya. Perbuatan ini, secara tabiat terjadi pada diri manusia di luar dayanya, dan karena itu tidak menjadi tuntutan syariat kecuali perbuatan lain yang berkaitan dengannya. Oleh karena itu, hadis yang bebunyi: أحبوا الله لما أسدي اليكم من نعمان (cintailah Tuhan berkat nikmat-nikamt yang dianugerakan kepadamu) menurut al-Syatibiy mengandung perintah untuk merenungkan segala nikmat dan kebaikan yang dianugerakan Tuhan kepada hamba-Nya. Dengan kata lain, perintah itu tidak langsung menunjuk hakikat cinta itu sendiri. Demikian pula larangan terhadap rangsangan syahwat yang dapat membawa kepada perbuatan haram, tidak tertuju kepada hakikat syahwat itu sendiri. ${ }^{37}$

Dalam beberapa pernyataan al-Syatibiy, ditemukan paling tidak ada tiga indikasi yang lebih menekankan efektifitas daya manusia dalam perbuatannya. Tiga indikasi yang dimaksud adalah kemampuan jasmani, kekuatan akal atau ilmu, dan kesengajaan berbuat yang disebut niat atau al-qashad.38 Tiga hal tersebut diuraikan satu persatu sebagai berikut:

1. Kekuatan jasmani merupakan faktor terpenting bagi terlaksananya perbuatan, yang karenanya daya jasmani menjadi syarat bagi pelaksanaan segenap hukum syariat. Atas dasar ini al-Syatibi menolak adanya hukum taklif yang tidak terjangkau oleh daya jasmani. Sebagai telah disinggung sebelumnya, keadaan yang secara tabiat pada manusia, misalnya nafsu makan dan nafsu seksual, kita tidak diminta oleh syariat untuk menghilangkannya sama sekali, karena hal itu di luar daya manusia.

2. Daya akal juga menjadi syarat mutlak berlakunya hukum taklif. Berdasarkan dalil wahyu dan akal, hukum taklif mustahil berlaku atas orang yang tidak berakal, sebagai halnya hukum atas hewan dan benda mati.

3. Bahwa suatu perbuatan dapat terwujud dan dinilai oleh syariat hanya apabila seseorang mempunyai niat dalam melakukannya.

37 Ibid., h. 153-154.

38 Ibid., h. 154. 
Menurut al-Syatibi, segenap hukum taklif yang lima: wajib, haram, sunat, makruh dan mubah adalah tergantung sepenuhnya pada kesengajaan manusia sebagai pelaku. Setidaknya ada tiga alasan untuk hal ini (1) Bahwa harus ada niat. (2) Bahwa diketahui pasti, setiap perbuatan yang lahir dari orang gila, tidur, anak-anak dan orang tak sadar adalah bebas dari hukum taklif. (3) berdasarkan ijma', beban di luar daya manusia tidak tejadi dalam syariat. ${ }^{39}$

\section{Tujuan Syariat Ditetapkan untuk Dipatuhi (Dilaksanakan) dan Mengeluarkan Mukallaf dari Pengaruh Hawa Nafsu}

Tujuan ditetapkannya syariat yang terakhir adalah mengeluarkan mukallaf dari pengaruh hawa nafsu sehingga menjadi hamba yang bebas (ikbtīyar) sebagaimana ia menjadi hamba yang terpaksa (i«tirar), untuk membuktikan pernyataan tersebut, maka berikut dikemukakan beberapa alasan: 40

1. Nash yang jarih menunjukkan bahwa tujuan diciptakannya hamba adalah untuk beribadah kepada Allah swt., mentaati perintah-Nya dan menjauhi larangan-Nya, untuk lebih jelasnya dapat dilihat sebagai berikut:

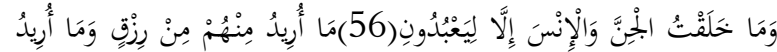

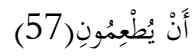

"Dan Aku tidak menciptakan jin dan manusia melainkan supaya mereka menyembah-Ku. Aku tidak menghendaki rezki sedikitpun dari mereka dan Aku tidak menghendaki supaya mereka memberi Aku makan". ${ }^{41}$ (Q.S. al-Zaariyaat [51]: 56-57).

lihat juga antara lain Q.S. 20: 132, Q.S. 2: 21 dan 177, Q.S. 4: 32.

2. Adanya nash yang menunjukkan celaan terhaadap orang yang melanggar tujuan syariat, yakni: menjauhi larangan, melanggar perintah dan celaan terhadap orang yang berpaling dari Allah swt. disertai dengan ancaman dan siksaan secara tidak langsung atas setiap pelanggaran, karena mereka dipengaruhi oleh hawa nafsu dan meninggalkan ketaatan. Hal tersebut dapat dilihat pada beberapa Ayat Alquran sebagai berikut:

\footnotetext{
39 Ibid. , h. 154-157.

40 Lihat al-Syatibiy, op. cit. , h. 128.

41 Dikutip dari CD Alquran (Govathu Collction).
}

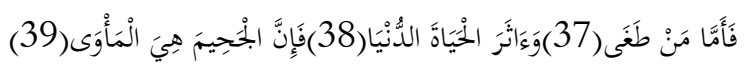

"Adapun orang yang melampaui batas, dan lebih mengutamakan kehidupan dunia, maka sesungguhnya nerakalah tempat tinggal (nya)". ${ }^{42}$ (Q.S. al-Naaziaat: [79] 37-39).

Lihat pula antara lain Q.S. 53: 3-4, Q.S. 45: 23, Q.S. 23: 71, Q.S. 47: 14.

3. kenyataan empirik dan tradisi menunjukkan bahwa maslahat keagamaan dan keduniaan tidak akan terwujud jika dilakukan dengan memperturutkan hawa nafsu. Karena nafsu cenderung berorientasi kepada pertumpahan darah. ${ }^{43}$

Dari uraian di atas, dapat dipahami bahwa di antara tujuan syariat adalah menghindarkan manusia dari memperturutkan hawa nafsu, karena maslahat tidak mungkin terwujud dengan baik bila seorang mukallaf cenderung memperturutkan hawa nafsu.

\section{Kesimpulan}

Setelah penulis mengemukakan beberapa pembahasan yang cukup sederhana di atas, maka berikut akan di kemukakan beberapa kesimpulan:

1. Maqashid al-syariah adalah makna-makna atau tujuan-tujuan yang ditetapkan bagi syariat dalam seluruh hukum-hukumnya atau pada umumnya, dengan kata lain maqashid al-syari'ah adalah rahasia-rahasia yang yang ditetapkan Allah swt. (al-Syari) bagi setiap hukum syariat.

2. Tujuan Tuhan menetapkan syariat ada empat: (1). Untuk kemaslahatan manusia di dunia dan akhirat. (2). Untuk dipahami. (3). Sebagai suatu hukum taklif yang harus dilaksanakan dan menghilangkan kesukaran. (4). Untuk dipatuhi dan membebaskan mukallaf dari pengaruh hawa nafsu. Tujuan yang pertama disebutkan merupakan tujuan utama, adapun tujuan-tujuan yang lain hanya merupakan penjelasan dan perincian dari yang pertama.

3. Untuk terwujudnya kemaslahatan tersebut, maka ada enam komponen penting yang harus dipelihara, yakni: agama, jiwa, akal, keturunan, harta, dan jamaah. Setiap enam komponen tersebut memiliki tiga unsur, yakni: unsur primer

2 Dikutip dari CD Alquran (Govathu Collction).

43 Lihat Ibid. , h. 129. 
(dharuriyah), sekunder (bajizah), dan tertier (tabsiniyab)

\section{Daftar Pustaka}

Abu Zahrah, Muhammad. Tarikh al-Mazahib alIslamiyah fi al-Siyāsah wa al-'Aqäid wa Tarikh al-Mazabib al-Fiqbiyah. Mesir: Dar al-Fikr al-'Arabiy, t. th.

Abu Zahrah, Muhammad. Ushl al-Figh. t. d.

Ahmad. Nazariah al-Maqashid inda al-Imam alSyatibiy. Cet. I; t. t: al-Muassasah alJami'iyah li al-Dirāsāt wa al-Nusyu wa alTauzi', 1992.

Al-Syatibiy. al-Muwafaqat fi Ushul al-Syari'ab, Juz II. Beirut: Dar al-Kutb al-'Ilmiayah, t. th.. Al-Zuhailiy, Wahbat Ushul al-Figh al-Islami, Juz II. Cet. II; Beirut: Dar al-Fikr, 1998. CD Alquran (Govathu Collction).
Djamil, Fathurrahman. Filsafat Hukum Islam, Bagian Pertama. Cet. I; Jakarta: Logos Wacana Ilmu, 1997.

Haq, Hamka. Palsafat Ushul Fiqh. Makassar: Yayasan Al-Ahkam, t. th.

Khallāf, Abd Wahhāb. Tlm Ushul al-Fiqh t. d.

Minhajuddin. Ikbtilaf Ulama Sunni dan Pengarubnya terbadap Perkembangan Fikib Islam dalam Zaitun. Volume I Nomor II Maret Tahun 2003.

Minhajuddin. Sistimatika Filsafat Hukum Islam Ibadah Mia'amalah Perkawinan Jinayat Peradilan Keadilan. Ujungpandang: Yayasan Ahkam, 1996.

S. Praja, Juhaya. Filsafat Hukum Islam. Cet. I; Bandung: Yayasan Piara Bandung, 1993.

Syah, Muhammad, dkk. Filsafat Hukum Islam. Cet. II; Jakarta: Bumi Aksara, 1992.

Syaripuddin, Amir. Ushul Figh, Jilid II. Cet. II; Jakarta: PT Logos Wacana Ilmu, 2001. 